\title{
ARBITRAGEM NA ADMINISTRAÇÃO PÚBLICA BRASILEIRA E INDISPONIBILIDADE DO INTERESSE PÚBLICO
}

\author{
Ana Lucia Pretto Pereira ${ }^{1}$ \\ Ana Elisa Pretto Pereira Giovanini ${ }^{2}$
}

\begin{abstract}
Resumo
Em que pese a Lei n. ${ }^{0}$ 13.129/15 tenha autorizado, expressamente, o uso da arbitragem por entes públicos, superando discussões fundadas em eventual ofensa ao princípio da legalidade, ainda se encontram na doutrina objeções ao uso dessa modalidade alternativa de solução de controvérsias no âmbito da Administração Pública, sob o argumento de violação ao princípio da indisponibilidade do interesse público. Nessa linha, o presente artigo objetiva analisar o conceito de interesse público pelo viés da supremacia e da indisponibilidade, discutindo os seus efeitos no uso da arbitragem na seara estatal. A metodologia utilizada foi a revisão bibliográfica de tema.
\end{abstract}

Palavras-chave: Administração Pública - Supremacia e Indisponibilidade do Interesse Público - Arbitragem Estatal

\section{INTRODUÇÃO}

A arbitragem é um método alternativo de resolução de conflitos cujo ingresso na esfera jurídica brasileira remonta à Constituição Imperial de 1824. À época, contudo, a configuração da arbitragem não era a mesma que hoje se experimenta, assim como não se revelava um meio eficaz para a solução de litígios, razão pela qual era pouco utilizada nas relações entre particulares ${ }^{3}$.

Por outro lado, na seara dos contratos administrativos firmados entre particulares e a Administração Pública, a arbitragem já era consideravelmente utilizada desde 1850, quando passou a vigorar o Código Comercial, o que se fazia nos moldes do Direito europeu, especialmente porque diversos desses contratos eram firmados com empresas estrangeiras e companhias criadas com capital público. À época, utilizava-se a arbitragem

\footnotetext{
${ }^{1}$ Doutora (2013) em Direito Constitucional pela Universidade Federal do Paraná, com estágio doutoral em Teoria do Direito na Universidade de Harvard (2012). Professora pesquisadora vinculada à Graduação e ao Mestrado em Direitos Fundamentais e Democracia no Centro Universitário Autônomo do Brasil. E-mail: anapereira@unibrasil.com.br

${ }^{2}$ Mestranda em Direito Processual Civil e Relações Negociais. E-mail: anaelisapp@hotmail.com

${ }^{3}$ Acerca do histórico da arbitragem no sistema jurídico brasileiro, vide CAHALI, Francisco José. Curso de Arbitragem: mediação: conciliação: resolução CNJ 125/2010. 5a ed. Revista e atualizada, de acordo com a Lei 13.129/2015 (Reforma da Lei de Arbitragem), com a Lei 13.140 (Marco Legal da Mediação) e o Novo CPC. São Paulo: Editora Revista dos Tribunais, 2015. p. 33 40, e FIGUEIRA JUNIOR, Joel Dias. Arbitragem (legislação nacional e estrangeira) e o monopólio jurisdicional. São Paulo: LTr, 1999. p. 32-35.
} 
na maioria dos contratos de concessão realizados entre o poder público e empresas estrangeiras".

Com a promulgação da Lei n.o 9.307, de 23 de setembro de 1996 - Lei da Arbitragem-, a arbitragem recebeu nova roupagem, abarcando as tendências mais modernas do instituto ${ }^{5}$. Atualmente, mostra-se uma alternativa técnica, econômica, rápida, eficaz, sigilosa e desburocratizada na resolução de conflitos que versem sobre direitos disponíveis, oriundos de contratos nacionais ou internacionais ${ }^{6}$. O fato de se tratar de uma via alternativa significa que, ao optarem os contratantes pela arbitragem, estarão renunciando ao caminho ordinário oferecido pelo Poder Judiciário.

Importante salientar que a arbitragem é apenas mais uma opção conferida aos litigantes para resolução de seus conflitos, de modo que não visa substituir ou concorrer com a jurisdição estatal. Trata-se de um mecanismo que, ao longo da história, vem se mostrando bastante eficaz, motivo pelo qual é utilizado nos mais diversos países especialmente para a resolução de grandes conflitos, sobretudo de natureza comercial interna e internacional?

Em que pese, de início, a Lei 9.307/96 não tenha previsto expressamente a utilização da arbitragem nos contratos administrativos que versassem sobre direitos disponíveis, a hermenêutica jurídica e o legislador trataram de incluí-la nessa seara por entenderem que a Administração Pública também se enquadraria no disposto pelo caput do art. $1^{\circ}$ dessa Lei.

Atualmente, com o advento da Lei 13.129/15, essa perspectiva foi consolidada normativamente e, em tese, suplantaram-se as discussões a respeito da legalidade da arbitragem na Administração Pública. Isso porque o legislador abarcou expressamente a possibilidade de os entes estatais utilizarem-se da arbitragem para a resolução de conflitos atinentes a direitos disponíveis, o que ocorreu com a inclusão do novo $\$ 1^{\circ}$ ao art. $1^{\circ}$ da Lei 9.307/96.

Nessa linha, versa o $\$ 1^{\circ}$, do art. $1^{\circ}$, da Lei 9.307/96 que "A administração pública direta e indireta poderá utilizar-se da arbitragem para dirimir conflitos relativos a direitos patrimoniais disponíveis", redação esta, portanto,

\footnotetext{
${ }^{4}$ A respeito desse aspecto histórico da arbitragem, vide LEMES, Selma Ferreira. A arbitragem na Administração Pública Fundamentos Juridicos e Eficiência Econômica. São Paulo: Quartier Latin. 2007. p. 63-83.

${ }^{5}$ Alguns dos motivos que tornaram arbitragem um método eficaz para a solução de conflitos foi a desnecessidade de o laudo arbitral submeter-se à homologação judicial, a execução específica e o reconhecimento da equivalência entre a cláusula compromissória e o compromisso arbitral, aos quais foi atribuída a qualidade de convenção de arbitragem. Acerca desse assunto, vide WALD, Arnoldo, in A recente evolução da arbitragem no direito brasileiro (1996-2001), in Reflexões sobre arbitragem: "In Memoriam" do Desembargador Cláudio Vianna de Lima. São Paulo: Editora LTR, 2002. p.147, e in Novos Rumos para a Arbitragem no Brasil, in Revista de Direito Bancário e do Mercado de Capitais. vol.14/2001. p. 341-356. Out-Dez/2001. DTR $\backslash 2001 \backslash 411$.

${ }^{6}$ A cláusula compromissória e, consequentemente, a arbitragem, encontram-se consolidadas há bastante tempo em diversos países designados desenvolvidos, como Bélgica e Suíça. Por essa razão, sua amplitude em matéria de direito público é consideravelmente mais extensa se comparada à essa mesmo seara no Brasil, assim como possui aspectos diversos em sua sistemática. Nesse diapasão, verifica-se enorme confiança na atuação da Administração Pública, tanto em contratos celebrados exclusivamente no âmbito público, quando em contratos que envolvam relações público-privadas. A esse respeito, vide RENDERS, David; DEVOLVÉ, Pierre; TANQUEREL, Thierry; BOMBOIS, Thomas (Coautor). L'arbitrage en droit public. Bruxelles, Belgique: Bruylant, 2010. XVII (Centre d'études constitutionnelles et administratives; 31)
} 
inédita no texto da lei.

Na seara processual civil, o atual código conferiu status de norma fundamental à arbitragem ao inseri-la ao capítulo que trata das normas fundamentais do processo. $\mathrm{O}$ caput do art. $3^{\circ}$ do novo código, reproduz o direito fundamental do acesso à justiça, nos termos previstos pela Constituição da República (art. 5o, inc XXXV). Ademais, os parágrafos $1^{\circ}$ a $3^{\circ}$, de citado artigo, expressamente consagram os métodos alternativos de resolução de conflitos.

Trata o $\$ 1^{\circ}$ da arbitragem, o $\$ 2^{\circ}$ da promoção pelo Estado de soluções consensuais aos conflitos, e o $\$ 3^{\circ}$ sobre o fomento por parte de juízes, advogados, defensores públicos e membros do Ministério Público aos métodos consensuais para a solução de conflitos e litígios em curso.

Diante disso, observa-se que, além da inovação trazida pela Lei da Arbitragem ao permitir que entes estatais utilizem-se do instituto para a resolução de conflitos que versem sobre direitos disponíveis, o novo Código de Processo Civil surge com o claro propósito de acolher e legitimar o uso desse instituto, o que faz à luz da constitucionalização do direito processual, que implica ordenar, disciplinar e interpretar o processo nos termos dos valores e normas fundamentais encartados na Constituição.

Embora, em um primeiro momento, a inclusão da Administração Pública no rol dos legitimados para o uso da arbitragem tenha solucionado discussões decorrentes da interpretação extensiva dada por doutrina e jurisprudência ao caput do antigo art. 1º, da Lei 9.307/96 - pois essa interpretação ofenderia o princípio da legalidade -, algumas das críticas e dúvidas anteriores à atual modificação permanecem em voga.

Parcela de mencionadas críticas diz respeito à suposta incompatibilidade entre o objeto da arbitragem e princípios basilares da Administração. Segundo a Lei da Arbitragem, será objeto desse instituto todo direito disponível oriundo de uma relação contratual. Assim, uma vez que o interesse público rege as ações estatais, e tendo em conta que o interesse público é indisponível, não seria possível a utilização da arbitragem pelos entes estatais, pois ofenderia o interesse público. E essa é, portanto, a questão posta sob análise.

\section{INTERESSE PÚBLICO: SUPREMACIA E INDISPONIBILIDADE}

O interesse público é um dos principais elementos norteadores da atividade exercida pela Administração Pública' ${ }^{9}$ especialmente porque presente no momento de elaboração da lei - ao direcionar o legislador -, e na

\footnotetext{
${ }^{7}$ FIGUEIRAJUNIOR, Joel Dias. Op. cit. p. 30-31.

${ }^{8} \mathrm{CPC} / 15$. Art. 1o. O processo civil será ordenado, disciplinado e interpretado conforme os valores e as normas fundamentais estabelecidos na Constituição da República Federativa do Brasil, observando-se as disposições deste Código.

${ }^{9}$ Utiliza-se a expressão Administração Pública para designar os entes que integram a Administração Pública Direta e Indireta, que são as designadas no art. 41, do Código Civil ('São pessoas jurídicas de direito público interno: I - a União; II - os Estados, o Distrito Federal e os Territórios; III - os Municípios; IV - as Autarquias, inclusive as associações públicas; V - as demais entidades de caráter público criadas por lei"), e as pessoas jurídicas vinculadas a esse Poder, consoante expresso pelo $\$ 1$ o, do art. 173, da Constituição da
} 
aplicabilidade da norma pelo agente público, cujos atos são a ela vinculados ${ }^{10}$. Isso porque o "estado é formado pela sociedade e deve perseguir os valores que ela aponta" ${ }^{11}$.

Por outro lado, embora o interesse público, regra geral, seja aquele alinhado aos interesses de uma determinada comunidade política, é possível que sua realização ocorra mediante a satisfação de certos interesses privados. Isso se dá, por exemplo, quando o interesse público resulta tutelado por uma cláusula de direito fundamental individual, o que torna indubitável o dever de sua proteção. Mas também poderá ocorrer em outras situações, quando não haja direitos fundamentais envolvidos ${ }^{12}$.

É entendimento assente na doutrina que a supremacia e a indisponibilidade do interesse público são elementos do regime jurídico de direito público. Por essa razão, "o direito não faculta ao agente público o poder para escolher entre cumprir e não cumprir o interesse público. O agente é um servo do interesse público - nessa acepção, o interesse público é indisponível ${ }^{13}$.

O interesse público consubstancia-se, portanto, no interesse de todos os indivíduos que compõem uma sociedade, seja ele atinente a interesses de maiorias ou minorias, razão pela qual não haveria um único interesse público, homogêneo e singular, mas vários interesses públicos, alguns conflitantes, inclusive, entre si. Não se trata o interesse público do interesse de um todo em abstrato, concebido em desconexão com os interesses individuais. Nessa linha, seria inadmissível que um interesse do todo se sobrepusesse ao interesse individual das partes que o compõe, pois o interesse do todo é, na realidade, função qualificada dos interesses das partes ${ }^{14}$.

Embora seja claro que pode haver um interesse público contraposto a um dado interesse individual, sem embargo, a toda evidência, não pode existir um interesse público que se choque com os interesses de cada um dos membros da sociedade. Esta simples e intuitiva percepção basta para exibir a existência de uma relação íntima, indissolúvel, entre o chamado interesse público e os interesses ditos individuais.

É que, na verdade, o interesse público, o interesse do todo, do conjunto social, nada mais é que a dimensão pública dos interesses individuais, ou seja, dos interesses de cada indivíduo enquanto partícipe da Sociedade (entificada juridicamente no Estado), nisto se abrigando também o depósito intertemporal destes mesmos interesses, vale dizer, já agora, encarados eles em sua continuidade histórica, tendo em vista a sucessividade das gerações de seus nacionais

(...)

Donde, o interesse público deve ser conceituado como o interesse resultante do conjunto dos interesses que os indivíduos pessoalmente têm quando considerados em sua qualidade

República ("A lei estabelecerá o estatuto jurídico da empresa pública, da sociedade de economia mista e de suas subsidiárias que explorem atividade econômica de produção ou comercialização de bens ou de prestação de serviços [...]").

${ }^{10}$ DI PIETRO, Maria Sylvia Zanella. Op. cit.p. 64.

${ }^{11}$ BARROSO, Luís Roberto. Op. cit. p. 92

${ }^{12}$ Nessa linha, vide BARROSO, Luís Roberto. Op. cit.p. 93.

${ }^{13}$ JUSTEN FILHO, Marçal. Curso de Direito Administrativo. 2a ed. São Paulo: Saraiva, 2006.p.35. (grifo do autor)

${ }^{14}$ Nesse aspecto, entende Marçal JUSTEN FILHO, in Op. cit., p. 47, que "O processo de democratização conduz à necessidade de verificar, em cada oportunidade, como se configura o interesse público. Sempre e em todos os casos, tal se dá por meio da intangibilidade dos valores relacionados aos direitos fundamentais". 
de membros da Sociedade e pelo simples fato de o serem. (grifos do autor) ${ }^{15}$.

O interesse público, portanto, não pode ser definido tomando-se por base a identidade do seu titular, sob pena de inversão lógica e axiológica de sua verdadeira função. Isso porque o Estado existe para satisfazer as necessidades coletivas. O interesse é reconhecido como público porque é indisponível, e não indisponível porque é público. Será público o interesse porque não pode ser colocado em risco, porque sua natureza exige que seja realizado ${ }^{16}$.

Inexiste, contudo, uma definição normativa expressa para interesse público, tampouco, observa-se, literalmente, a supremacia e a indisponibilidade do interesse público como princípios constitucionais, o que não significa, porém, que não tenham sido tutelados pelo constituinte. A interpretação e a concretização do que seja entendido como interesse público deve partir de determinações na própria Constituição da República especialmente suas normas fundamentais e aquelas contidas no art. 37 -, cumuladas com as demais normas infraconstitucionais correspondentes. ${ }^{17}$

Há doutrinadores que criticam ${ }^{18}$ a expressão interesse público por entenderem que não possui conteúdo próprio. Ademais, não poderia o interesse público ser definido apenas como sinônimo de interesse coletivo. Por esse motivo, jamais poderia ser utilizado como base estrutural da Administração Pública e do direito administrativo. Em razão disso, sugerem que a democracia e o respeito aos direitos fundamentais sejam a mola mestra do regime jurídico de direito público, e não a invocação genérica do interesse público, eis que incompatível com o Estado Democrático de Direito.

Nessa seara, apresenta-se mais coerente o entendimento de que são múltiplos os interesses públicos, uma vez que são inúmeros os objetivos constitucionais e serem cumpridos pela Administração Pública, sejam estes à coletividade como um todo, a parcela dela ou a apenas um indivíduo. Essa multiplicidade é tamanha que é perfeitamente possível que haja conflito entre interesses públicos pertencentes a um único indivíduo e à coletividade ou entre grupos distintos, o que é solucionável utilizando-se o critério da proporcionalidade.

No que concerne à identificação da existência ou não de interesse público em determinada situação, parte da doutrina entende que devem ser levados em conta os objetivos contextuais daquela circunstância em concreto, o que se faz à luz dos contextos social e normativo específicos ao caso. Há relativo abandono do conceito tradicional de interesse público, pois, em virtude de sua generalidade, calcada em situações não contextualizadas, não se mostra capaz de alcançar com eficácia os objetivos específicos do Estado.

O interesse público, nessa medida, deve ser adequadamente verificado com a consideração dos objetivos contextuais, previstos no ordenamento jurídico e aos quais determinada ação

\footnotetext{
${ }^{15}$ MELLO, Celso Antônio Bandeira de. Curso de Direito Administrativo. 26. ed. rev. e atual. São Paulo: Malheiros, 2006. p.49-51.

${ }^{16}$ JUSTEN FILHO, Marçal. Op. cit. p.43.

${ }^{17}$ RODRIGUES, Marco Antonio. A fazenda pública no processo civil. São Paulo: Atlas, 2016. p. 8-9.

${ }^{18}$ JUSTEN FILHO, Marçal. Idem. p.35-47.
} 
administrativa está relacionada. Sua avaliação não deve limitar-se apenas ao altíssimo grau de generalidade de sua definição tradicional, que conduz à sua consideração apenas como um objetivo acontextual, distante de um contexto valorativo determinado.

A consideração contextualizada do interesse público abre espaço para negociação e para a solução consensual de controvérsias, compondo interesses públicos e particulares. Com efeito, considerado o interesse público no contexto de objetivos normativos específicos, é necessário admitir a existência de uma gama de possibilidades lícitas e viáveis de seu atingimento. Com isso, é possível mesmo sem dispor do "interesse público", negociar quanto à maneira de atingi-lo em determinado contexto ${ }^{19}$.

No âmbito dos contratos administrativos, quando o Estado participa de uma relação jurídica, esta será norteada por um regime jurídico específico, que é o regime de direito público. Do mesmo modo, a atuação dos agentes estatais também é diferenciada se comparada às relações intersubjetivas exclusivamente privadas, uma vez que "não agem em nome próprio nem para seu autodesfrute" 20 . Ademais, "as condutas praticadas no exercício de competências públicas estão sujeitas a regras e princípios específicos (...). No espaço público, não reinam a livreiniciativa e a autonomia da vontade, estrelas do regime jurídico de direito privado"21.

Nessa linha, Celso Antonio Bandeira de $\mathrm{MELLO}^{22}$ esclarece a principal diferença entre o interesse público e o interesse privado:

A Administração Pública está, por lei, adstrita ao cumprimento de certas finalidades, sendolhe obrigatório objetivá-las para colimar interesse de outrem: o da coletividade. É em nome do interesse público - o do corpo social - que tem de agir, fazendo-se na conformidade da intentio legis. Portanto, exerce "função", instituto - como visto - que se traduz na ideia de indeclinável atrelamento a um fim preestabelecido e que deve ser atendido para o benefício de um terceiro. É situação oposta à da autonomia da vontade, típica do Direito Privado. De regra, neste último alguém busca, em proveito próprio, os interesses que lhe apetecem, fazendo-o, pois, com plena liberdade, contanto que não viole alguma lei.

Onde há função, pelo contrário, não há autonomia da vontade, nem a liberdade em que se expressa, nem a autodeterminação da finalidade a ser buscada, nem a procura de interesses próprios, pessoais. Há adscrição a uma finalidade previamente estabelecida, e, no caso de função pública, há submissão da vontade ao escopo pré-traçado na Constituição ou na lei e há o dever de bem curar um interesse alheio, que, no caso, é o interesse público; vale dizer, da coletividade como um todo, e não da entidade governamental em si mesma considerada. (grifamos)

No que concerne à supremacia do interesse público, esta é considerada "princípio geral de Direito inerente a qualquer sociedade. É a própria condição de sua existência (...) especialmente porque se trata de pressuposto lógico do convívio social. " ${ }^{23}$ Isso significa dizer que a mola mestra da atuação estatal consiste na busca e na proteção do interesse público, de modo que tal objetivo deve estar acima de qualquer interesse que juntamente deste não possa subsistir.

Há inúmeras passagens no texto constitucional que aludem concretamente a mencionado princípio,

\footnotetext{
${ }^{19}$ SALLES, Carlos Alberto de. Arbitragem em contratos administrativos. Rio de Janeiro: Forense; São Paulo: Método, 2011.p. 129.

${ }^{20}$ BARROSO, Luís Roberto. Op.cit. p. 92.

${ }^{21}$ Idem. Ibidem.

${ }^{22}$ MELLO, Celso Antônio Bandeira de. Op. cit. p.87.

${ }^{23}$ MELLO, Celso Antônio Bandeira de. Op. cit. p.85.
} 
como os institutos da desapropriação e da requisição (art. $5^{\circ}$, XXIV e XXV), nos quais a supremacia do interesse público sobre o interesse privado é cristalina.

Preleciona Celso Antonio Bandeira de MELLO que todo o sistema do Direito Administrativo se constrói sobre os princípios da supremacia e da indisponibilidade do interesse público, os quais se expressam no binômio prerrogativas da Administração - direitos dos administrados. Contudo, mencionado jurista destaca que não é dado a esses princípios um valor intrínseco, perene e imutável ${ }^{24}$.

Por representar o interesse público, a Administração Pública, como expressão da supremacia desse princípio, é legalmente dotada de prerrogativas não conferidas aos particulares. Contudo, tais prerrogativas "não são manejáveis ao sabor da Administração (...) que jamais dispõe de poderes, sic et simpliciter. Na verdade, o que nela se encontram são 'deveres-poderes' (...) porque a atividade administrativa é desempenho de 'função'"25.

Cumpre salientar que parcela da doutrina atual critica $^{26}$ a supremacia do interesse público, pois a considera mitigável frente à atual configuração constitucional e principiológica do sistema jurídico brasileiro. $\mathrm{O}$ entendimento é no sentido de que é necessário "rediscutir e dessacralizar o chamado princípio da supremacia do interesse público"27, mas de forma alguma desconectá-la por completo da posição tradicional. Isso porque há situações nas quais haverá colisão entre os interesses do Estado e da coletividade, de modo que, nessas situações, é necessário que o intérprete observe, especialmente, dois parâmetros: "a dignidade humana e a razão pública"28.

Diretamente ligado ao princípio da supremacia está a indisponibilidade do interesse público, que são os "interesses qualificados como próprios da coletividade - internos ao setor público -, não se encontram à livre disposição de quem quer que seja, por inapropriáveis" ${ }^{29}$. Assim, por se tratarem de interesses pertencentes à coletividade, cabe ao órgão administrativo apenas geri-los, em estrita conformidade com o disposto em lei, deles não podendo dispor livremente.

Nessa linha, portanto, a indisponibilidade consiste na garantia de que os bens públicos serão utilizados

\footnotetext{
${ }^{24}$ Idem. p.46-47.

${ }^{25}$ Idem. p.86.

${ }^{26}$ Essa crítica, suscitada, dentre outros, por BARROSO, Luis Roberto, in Op. cit. p.92-95, decorre de classificação de origem italiana e difundida, inicialmente, por MELLO, Celso Antônio Bandeira de, in Op. cit. p.87-88, acerca da divisão do interesse público em primário e secundário. O interesse primário seria a razão de ser do Estado, a finalidade que lhe fora consagrada por lei (promoção da justiça, saúde, segurança, educação, etc.); é o interesse pertencente à coletividade. Já o interesse público secundário seria o interesse da própria pessoa jurídica de direito público quando participa de uma relação jurídica, a qual deve buscar maximizar a arrecadação e minimizar despesas. Em um Estado Democrático de Direito, portanto, é o interesse público primário que desfruta de supremacia, uma vez que ele é o parâmetro da ponderação nas relações jurídicas e sociais. E mais, havendo colisão entre interesse público primário coletivo e interesse público primário privado fundado em direito fundamental, consoante afirma Barroso, o intérprete deverá observar, sobretudo, os parâmetros da dignidade humana e da razão pública. Isso porque "para que um direito fundamental seja restringido em favor da realização de uma meta coletiva, esta deve corresponder aos valores políticos fundamentais que a Constituição consagra, e não apenas ao ideário que ocasionalmente agrega um número maior de adeptos" (op.cit.p.95).

${ }^{27}$ BARROSO, Luís Roberto. Op. cit. p.94

${ }^{28}$ Idem. ibidem.
} 
em prol e segundo os interesses da coletividade. Não podem ser disponibilizados pela Administração e seus Agentes, aos quais cabe apenas gerir, conservar e zelar por esses bens, eis que não são titulares desses interesses. $O$ Estado deve proteger esses interesses por meio da função administrativa, a qual é realizada pelos órgãos da administração, que nada mais são que veículos da vontade estatal expressamente disposta em lei ${ }^{30}$.

\section{A ARBITRAGEM NA SEARA ESTATAL E A INDISPONIBILIDADE DO INTERESSE PÚBLICO}

Trata-se a arbitragem de método alternativo para a resolução de conflitos de natureza patrimonial disponível, caracterizado pela sua consensualidade originária. Uma vez acatada a arbitragem, consensualmente, pelas partes contratantes, renuncia-se à justiça estatal para a resolução de eventuais conflitos atinentes aos direitos disponíveis contratualmente celebrados. Considerando os princípios e interesses que norteiam a atividade administrativa, em especial a indisponibilidade do interesse público, surgem questionamentos e objeções ao uso da arbitragem pelos entes estatais. Há, portanto, dissenso doutrinário a respeito da utilização da arbitragem pela Administração ${ }^{31}$.

A doutrina contrária ao uso da arbitragem pelos entes estatais alicerçou seu entendimento no fato de que a Administração Pública, uma vez que norteada por princípios cuja observância é obrigatória ${ }^{32}$, ao utilizar-se da justiça arbitral, acabaria por desrespeitar alguns princípios, dentre os quais destaca com maior veemência a indisponibilidade do interesse público pelo agente público, pois levará à arbitragem discussão a respeito de bens que podem vir a ser indisponíveis.

Segundo essa corrente, "todo e qualquer direito do qual seja titular uma entidade integrante da Administração seria indisponível e, por isso, insuscetível de ser discutido em procedimento arbitral”33. Além disso,

\footnotetext{
${ }^{29}$ MELLO, Celso Antônio Bandeira de. Op. cit. p.62.

${ }^{30}$ Idem. p. 63.

${ }^{31}$ De maneira um pouco diversa da que ocorre no Brasil, Manuel Pereira BARROCAS, doutrinador português, em sua obra Manual de Arbitragem. Coimbra: Almedina, 2010. p. 94-96, destaca que em Portugal, a arbitragem no âmbito dos contratos celebrados entre a Administração Pública e o particular, decorre de exigência do próprio particular em face do ente estatal, e está limitada a três questões: a) atinentes ao contrato administrativo, incluindo a apreciação de atos administrativos relativos à execução do contrato; b) questões de responsabilidade civil extracontratual, incluindo a efetivação do direito de regresso; e c) questões relativas aos atos administrativos que possam ser revogados com um fundamento que não seja sua invalidade.

32 Acerca dos princípios que regem a Administração Pública, vide MELLO, Celso Antônio Bandeira de. Curso de direito administrativo. 20a edição. São Paulo: Ed. Malheiros. 2006. p. 84-123; e DI PIETRO, Maria Sylvia Zanella. Direito Administrativo. $23^{a}$ ed. São Paulo: Atlas. 2010. p. 62-89.

${ }^{33}$ Embora adotando posicionamento diverso, Carlos Ari Sundfeld e Jacinto Arruda Câmara elaboram uma síntese de argumentos contrários ao uso da arbitragem em contratos administrativos: "...apesar dessas impugnações, não vislumbramos impedimento jurídico à realização de arbitragem que tenha como objeto a discussão de contratos administrativos". Cfr. CÂMARA, Jacinto Arruda. SUNDFELD, Carlos Ari. O cabimento da Arbitragem nos Contratos Administrativos. Revista de Direito Administrativo. Ed. Atlas. Disponível em <http://bibliotecadigital.fgv.br/ojs/index.php/rda/article/viewFile/41529/40879>. Acesso em 02/02/2016.p. 118.
} 
em respeito ao princípio da legalidade, não poderia a Administração Pública renunciar a direitos ou prerrogativas que a justiça estatal lhe confere em detrimento do uso da arbitragem, na qual tais garantias seriam suprimidas ${ }^{34}$.

Parte dessa discussão surge de analogia feita por alguns doutrinadores entre o compromisso arbitral e a transação, para os quais a capacidade para se submeter à arbitragem supunha também a de transigir. Ocorre que, transação significa comum acordo entre as partes para se colocar fim a um litígio; já a arbitragem implica submissão do conflito à decisão de árbitros escolhidos pelas partes, renunciando-se à justiça estatal. Trata-se de institutos distintos, tanto que possuem natureza e efeitos distintos.

Fazendo-se uma digressão histórica, o único texto legal que vinculou a capacidade para firmar compromissos arbitrais e a transação foi o Decreto n. 3.900 de 1867, que dispôs em seu art. $4^{\circ}$ que "podem fazer compromisso todos os que podem transigir". Com isso, apenas poderiam firmar compromissos aqueles que também pudessem transacionar. Essa disposição vigorou até a entrada em vigor do Código Civil de 1.916, que resgatou o conceito de que poderá firmar a arbitragem aquele que possui poder de contratar e, atinente à transação, vinculou-a ao objeto, e não ao sujeito, de modo que seriam transacionáveis apenas direitos disponíveis ${ }^{35}$.

Contudo, a analogia realizada por alguns doutrinadores entre o compromisso arbitral e a transação gerou o equivocado argumento de que se a Administração Pública não poderia transacionar, igualmente não poderia firmar a arbitragem, em respeito ao interesse público, que seria indisponível. Sustentava-se esse argumento no art. 1.037 do CC/16 e nos arts. 1.031 e 1.046 do CPC/73, que não esclareciam as matérias que poderiam ser objeto de arbitragem, mas faziam remissão ao art. 1.048 do CC/16, que dispunha aplicar-se a arbitragem naquilo que se aplicasse a transação ${ }^{36}$.

Nessa linha, não é possível que se diga que ao se submeter a arbitragem o ente público estaria transigindo com o interesse púbico, pois apenas desloca o litígio da seara judicial para a arbitral. Trata-se, portanto, de um equívoco correlacionar ou submeter a arbitragem à transação, pois a vinculação entre ambas reside apenas na matéria a que são passíveis de discussão, que são os direitos indisponíveis, nada mais sendo correlacionável entre ambas.

Atualmente, o entendimento majoritário é no sentido de que o uso da arbitragem além de autorizado, é recomendável, pois privilegia o interesse público ${ }^{37}$, especialmente em função da celeridade do procedimento e da inexistência de qualquer desrespeito à carta constitucional ${ }^{13}$. Ademais, "a adoção de mecanismos eficientes de

\footnotetext{
${ }^{34}$ Cfr.Idem. Ibidem.

${ }^{35}$ LEMES, Selma Ferreira. Op. cit. 71.

${ }^{36}$ LEMES, Selma Ferreira. Op. cit. p 71-72.

${ }^{37}$ GRAU, Eros Roberto. Arbitragem e contrato administrativo. Revista da Escola Paulista da Magistratura. Volume 3. Número 2 julho/dezembro 2002. São Paulo, SP: Escola Paulista da Magistratura. Imprensa Oficial do Estado. p.50.

${ }^{38}$ Nesse sentido, o Ministro Luiz FUX, em julgado paradigmático, destaca que “ (...) 12. Em verdade, não há que se negar a
} vol.10, nº. 02, Rio de Janeiro, 2017.pp. 1146-1161 
solução das controvérsias é tendente a reduzir o custo total dos contratos, pois reduz os riscos contratuais associados às perdas decorrentes de eventual litigância em juízo" ${ }^{\prime \prime 2}$. Nessa linha, destaca-se escólio de Themístocles CAVALCANTI, citado em parecer de autoria de Eros Roberto GRAU ${ }^{40}$ :

Parece-me que a administração realiza muito melhor os seus fins e a sua tarefa, convocando as partes que com ela contratarem, a resolver as controvérsias de direito e de fato perante o juízo arbitral, do que denegando o direito das partes, remetendo-as ao juízo ordinário ou prolongando o processo administrativo, com diligências intermináveis, sem um órgão diretamente responsável pela instrução do processo ${ }^{41}$.

Do mesmo modo, utilizar o termo interesse público de uma forma genérica como fator impeditivo para a realização de métodos autocompositivos de resolução de conflitos acaba por prejudicar a melhoria do funcionamento da própria máquina estatal. Já não mais é compatível com a atual estrutura social, econômica e jurídica do Estado Brasileiro essa noção genérica de interesse público, pois incapaz de regular com efetividade as atividades estatais, embora sirva como condicionante de suas ações ${ }^{42}$.

Outro aspecto relevante levantado pela doutrina é a especialidade trazida pela justiça arbitral ao ser possível o julgamento de uma disputa por pessoa tecnicamente especializada no objeto em discussão. Nessa perspectiva, estar-se-ia respeitando o "interesse público primário, cuja indisponibilidade, ao contrário de proibir sua utilização, estaria a exigir que a Administração Pública viesse a valer-se da arbitragem" ${ }^{\text {"43 }}$.

Ademais, os defensores da arbitragem na Administração Pública entendem que aquele que recorre à arbitragem não renuncia a direito algum, apenas opta por outra via, diversa do Poder Judiciário, para defender os interesses que acredita possuir. Assim, a noção de arbitrabilidade como renúncia deve ser afastada, pois engendra concepções ideológicas que não mais se coadunam com a atual ordem econômica, política e social, o que

aplicabilidade do juízo arbitral em litígios administrativos, em que presentes direitos patrimoniais do Estado, mas, ao contrário, até mesmo incentivá-la, porquanto mais célere (...). 15. É cediço que o juízo arbitral não subtrai a garantia constitucional do juiz natural, ao contrário, implica realiza-la, porquanto somente cabível por mútua concessão entre as partes, inaplicável, por isso, de forma coercitiva, tendo em vista que ambas as partes assumem o 'risco' de serem derrotadas na arbitragem”. (STJ. Ag Rg no MS 11.308/DF. 1a Seção. Rel. Min. Luiz Fux. Jgto em 28.06.2006, DJ 14.08.2006, p.251). Na mesma linha, Arnoldo WALD e André SERRÃO, in Aspectos Constitucionais e Administrativos da Arbitragem nas Concessões. Revista de Arbitragem e Mediação. vol. 16/2008. p.11-32. jan-mar/2008. São Paulo: Editora Revista dos Tribunais. p. 22, afirmam que o uso da arbitragem pela Administração seria "uma projeção do interesse público em obter essa organização e procedimento jurisdicional juridicamente seguro, célere e especializado, sob o imperativo do princípio da eficiência da Administração Pública inserto no art. 37, caput, da CF/1988. Também neste sentido, poder-se-ia invocar o art. 5. ${ }^{\circ}$ LXXVIII, da CF/1988, introduzido pela EC 45/2004, que se aplica tanto aos processos judiciais quanto aos processos administrativos".

${ }^{39}$ SALLES, Carlos Alberto de. Op. cit. p. 127.

${ }^{40}$ Da arbitrabilidade de Litígios Envolvendo Sociedades de Economia Mista e da Interpretação de Cláusula Compromissória. Revista de Direito Bancário, do Mercado de Capitais e da Arbitragem, ano 5. n. 18. out-dez/2002. São Paulo: Editora Revista dos Tribunais. p. 399.

${ }^{41}$ Segundo LEMES, Selma Ferreira., in Op.cit. p 65, esta recomendação foi dada por Themístocles Brandão Cavalcanti, Consultor Geral da República à época, no ano de 1955, para dirimir conflito havido em razão de desavenças quanto aos bens imóveis que, segundo os proprietários da concessionária "São Paulo Railway", não integrariam os bens encampados. Mencionada concessão foi estabelecida por Barão de Mauá em 1856, com prazo de duração de 90 anos. Em razão das desavenças citadas, que se arrastaram do término da concessão, em 1946, a 1955, houve essa recomendação para que a questão fosse dirimida por meio da arbitragem.

${ }^{42}$ SALLES, Carlos Alberto de. Idem. p. 128 
consolida o entendimento de que o julgamento de litígios pelo Estado não é superior ao julgamento realizado pelos árbitros ${ }^{44}$.

Cumpre trazer à baila o fato de que quando a lei de arbitragem delimitou sua aplicabilidade apenas para questões que envolvessem direito disponível, ela "afastou de seu âmbito de aplicação apenas os temas que não admitissem contratação pelas partes" ${ }^{\text {"45 }}$, ou seja, aplica-se aos direitos negociáveis que sejam objeto de atos de gestão da Administração ${ }^{46}$. Por essa razão, não seria possível contrapor-se ao uso dessa sistemática à luz de argumentos como o da indisponibilidade do interesse público.

Embora o Poder Público não possa disponibilizar de seus recursos com a mesma liberdade com que os particulares disponibilizam de seus, nada impede que empregue a arbitragem à luz da necessidade e da razoabilidade, sendo esta mais uma faceta que demonstra respeito ao interesse público. Tais perspectivas, na realidade, nada mais são do que a própria configuração da gestão do interesse público, a qual não se confunde com a indisponibilidade do patrimônio público. Ademais, não há que se confundir o interesse da coletividade com o interesse do aparato estatal.

Sob uma perspectiva jurisdicional, "a indisponibilidade do interesse público não representa a indisponibilidade do processo judicial" ${ }^{\text {47 }}$. Isso porque os meios utilizados para atingir a "tutela ao interesse da coletividade são disponíveis e se encontram numa esfera de escolha justificada pelo administrador, que tem o poder-dever de buscar o melhor método para atingi-lo" ${ }^{\text {"38 }}$.

Para tanto, à luz dos princípios constitucionais que norteiam a Administração Pública e dos interesses públicos envolvidos, o administrador deverá efetuar um "juízo de proporcionalidade, a fim de avaliar se a arbitragem é o método mais adequado para a solução de controvérsias relativas a determinado contrato" ${ }^{49}$. Constatado que o juízo arbitral seria o meio mais adequado para a resolução do conflito ou de eventuais conflitos futuros, a limitação ao objeto da arbitragem necessariamente deverá ser respeitada.

Para Eros Grau, "a doutrina tem tropeçado em injustificada confusão entre indisponibilidade do interesse público e disponibilidade de direitos patrimoniais. Um e outro não se confundem"50; e mais, afirma que "indisponível é o interesse público primário, não o interesse da Administração"s1, esta entendida como interesse

\footnotetext{
${ }^{43}$ WALD, Arnoldo. SERRÃO, André. Op. cit.p. 22.

44 Cfr. FRANZONI, Diego. Arbitragem societária. São Paulo: Editora Revista dos Tribunais, 2015. Coleção Liebman/coordenação Teresa Arruda Alvim Wambier, Eduardo Talamini. P. 109-110.

${ }^{45}$ CÂMARA, Jacinto Arruda. SUNDFELD, Carlos.Ari. Op. cit. p.120.

${ }^{46}$ Acerca do conceito dos atos de gestão e de império praticados pela Administração Pública, vide Celso Antônio Bandeira de MELLO. Op. cit. p.399-400.

${ }^{47}$ RODRIGUES, Marco Antônio. Op. cit.p. 369.

${ }^{48}$ Idem. Ibidem.

${ }^{49}$ Idem. p. 388.

${ }^{50}$ GRAU, Eros Roberto. Op. cit. p. 56.

${ }^{51}$ Idem. Ibidem.
} 
público secundário. (grifo do autor)

Quando a lei de arbitragem delimitou sua aplicabilidade apenas para questões que envolvam direito disponível, ela "afastou de seu âmbito de aplicação apenas os temas que não admitissem contratação pelas partes" ${ }^{\prime \prime 2}$, ou seja, aplica-se aos direitos negociáveis que sejam objeto de atos de gestão da Administração ${ }^{53}$. A arbitragem, portanto, não admite matéria de ordem pública. Por esse motivo, os casos de "inadmissibilidade da arbitragem em relação ao Poder Público são aqueles marcados pela objetiva indisponibilidade do direito ou dos poderes do Estado, e não pela razão subjetiva representada pela simples presença de um ente público na relação" ${ }^{\text {"4 }}$. (grifo do autor)

Esses direitos disponíveis a que se refere a lei são aqueles que podem ser transferidos ou alienados por seus titulares a terceiros. Nessa linha, todo direito passível de contratação pela Administração Pública também pode ser objeto de arbitragem ${ }^{55}$. Isso significa que o que autoriza a administração a submeter-se à arbitragem é seu poder de contratar.

Consoante exposto, é obrigação da Administração Pública o estrito cumprimento dos princípios que a norteiam. Isso significa que, independentemente de encontrar-se em litígio judicial, juízo arbitral ou qualquer outro método de resolução de conflitos, deverá cumprir citados princípios. A derrota da Administração Pública na seara arbitral não significa afronta ao interesse público. Apenas significa que o interesse público em favor da Administração não estará presente ${ }^{56}$.

Isso significa que uma vez identificado pelo ente público que o interesse em jogo não pertence à administração pública e que se trata de pretensão infundada, deverá reconhecer e respeitar os direitos do administrado, o que, indubitavelmente, é atender ao interesse público. Isso significa que todo direito deve ser cumprido independentemente de processo judicial ou juízo arbitral. Trata-se, portanto, de respeito à legalidade e à moralidade administrativas ${ }^{57}$.

Por essa razão, relativamente à disponibilidade do direito, tratando-se de conflito exclusivamente patrimonial e que verse sobre matéria que poderia ser resolvida pelas próprias partes, sem a imprescindível intervenção estatal, então a arbitragem será cabível. Exemplo disso são as ações de interesses eminentemente patrimoniais e cujo objeto tenha cunho econômico, ou cujo inadimplemento possa ser reparado, compensado ou

\footnotetext{
${ }^{52}$ CÂMARA, Jacinto Arruda. SUNDFELD, Carlos Ari. Op. cit. p.120.

${ }^{53}$ Acerca do conceito dos atos de gestão e de império praticados pela Administração Pública, vide Celso Antônio Bandeira de MELLO. Op. cit.p.399-400.

${ }^{54}$ DINAMARCO, Cândido Rangel. A arbitragem na teoria geral do processo. São Paulo: Ed. Malheiros. 2013. p. 89.

${ }^{55}$ RODRIGUES, Marco Antonio. Op. cit.p. 389.

${ }^{56}$ Idem. Ibidem.

${ }^{57}$ TALAMINI, Eduardo. A (in)disponibilidade do interesse público: consequências processuais (composições em juízo, prerrogativas processuais, arbitragem e ação monitória). Disponível em <https://www.academia.edu/231461/A_in_disponibilidade_do_interesse_p\%C3\%BAblico_consequ\%C3\%AAncias_process 
combatido por medidas com conteúdo econômico ${ }^{58}$.

Evidentemente que o interesse público é sempre indisponível pela Administração Pública por tratar-se de bem de titularidade coletiva, e não pertencente ao poder público. Por essa razão, a Administração se restringiria a administrá-lo, protegê-lo e conferir-lhe efetividade ${ }^{59}$. Como visto, em que pese o interesse público seja sempre indisponível, é possível que os direitos patrimoniais relacionados aos bens públicos não o sejam. "Por vezes, a disponibilidade de um patrimônio público pode ser de mais interesse da coletividade do que a sua preservação" ${ }^{60}$.

Ademais, invocar o princípio da indisponibilidade para impedir que a Administração Pública faça acordos, mediações ou arbitragens é incompatível com os resultados trazidos por essas práticas, pois o "interesse público realiza-se plenamente, sem ter sido deixado de lado, na rápida solução de controvérsias, na conciliação de interesses, na adesão de particulares às suas diretrizes, sem os ônus e a lentidão da via jurisdicional”61.

Nessa linha, segundo Eduardo TALAMINI ${ }^{62}$, o interesse público não coincide necessariamente com as posições concretas defendidas pelos ocupantes de cargos públicos, assim como a noção de interesse público não pode ser utilizada como pretexto para que a Administração não cumpra os valores fundamentais do ordenamento.

Nessa linha, portanto, a disponibilidade de direitos patrimoniais não se confunde com a indisponibilidade do interesse público, razão pela qual sempre que cabível a contratação pela Administração, o que só ocorre porque existe a disponibilidade de direito patrimonial, esta também poderá utilizar-se da arbitragem, sem que isso implique disposição do interesse público ${ }^{63}$.

\section{CONSIDERAÇÕES FINAIS}

A arbitragem, como método alternativo para resolução de conflitos atinentes a direitos disponíveis, vem sendo utilizada há décadas, tanto na seara pública quanto na privada, nos mais diversos países do mundo, eis que se mostra um método técnico, célere, econômico, sigiloso e desburocratizado de excelente eficácia. E o Brasil inclui-se dentre esses países, vez que a arbitragem faz parte das relações contratuais pactuadas entre o Poder Público e empresas estrangeiras desde a época da Constituição Imperial, do ano de 1824. Todavia, com o advento de outros paradigmas e legislações, foi paulatinamente perdendo força e acabou tendo seu uso de certa forma mitigado, especialmente na seara da Administração Pública.

Contudo, com o advento da Lei 9.307/96, houve uma remodelação da antiga arbitragem, de modo que

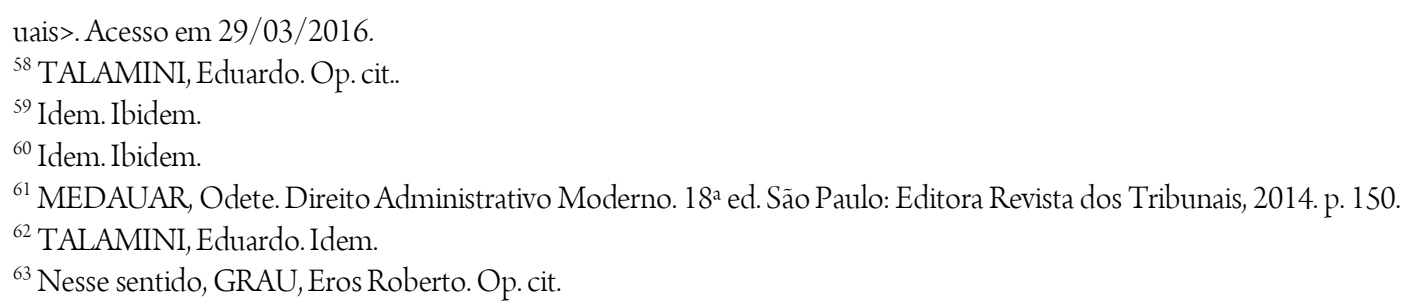


se iniciou um novo ciclo, sob uma roupagem mais moderna e compatível com as legislações internacionais. Juntamente das novidades trazidas por essa lei, iniciou-se discussão acerca da possibilidade de uso da arbitragem pela administração pública, pois não havia disposição expressa em seu texto, permitindo a participação de entes públicos, assim como parcela dos operadores jurídicos entendiam que seu uso poderia ferir determinados princípios norteadores da Administração, dentre os quais está a indisponibilidade do interesse público, que fora objeto deste artigo.

Em que pese a Lei 13.129/15 tenha incluído expressamente a possibilidade de a arbitragem ser utilizada pela administração, suplantando as controvérsias a esse respeito, as discussões a respeito da impossibilidade do uso da arbitragem pela Administração Pública permaneceram quanto à impossibilidade de livre disposição do interesse público por parte do agente público em contratos firmados entre a Administração e o particular.

Contudo, de todo o exposto, verifica-se que tal objeção decorre de confusão realizada por parcela da doutrina atinente aos conceitos de indisponibilidade do interesse público e disponibilidade de bens públicos, uma vez que a arbitragem tem por objeto questões atinentes a direitos disponíveis. Contudo, não há que se confundir tais conceitos.

Por conta disso, o entendimento consolidado é no sentido de que o interesse público -este entendido como o respeito à democracia e aos direitos fundamentais constitucionalmente garantidos a todos indiscriminadamente -, será sempre indisponível, pois não cabe ao Poder Público dele dispor, mas administrar, proteger e conferir efetividade. Em contrapartida, direitos disponíveis - que são aqueles passíveis de disposição pelo ente estatal mediante contratação -, estes, sim, podem ser objeto de arbitragem. Isso porque, todo bem passível de submissão a contratação pelo ente estatal, tem nesta disponibilidade também a possibilidade de ser submetido ao crivo do juízo arbitral.

Portanto, a utilização da arbitragem na seara pública, desde que realizada à luz dos princípios e regras constitucionais - também basilares para o Direito Administrativo -, permite compreender que o interesse público pode, em última ratio, vir a ser protegido. Por essa razão, a indisponibilidade desse interesse não se mostra, a priori, incompatível com a arbitragem, que é meio legítimo para atingimento dos objetivos da Administração Pública em favor da coletividade.

\section{ARBITRATION IN BRAZILIAN PUBLIC ADMINISTRATION AND THE PRINCIPLE OF PUBLIC INTEREST'S UNAVAILABILITY}

\section{Abstract}

Even after the federal statute n. 13.129/15 has clearly authorized the use of arbitration by public entities, discussions regarding some sort of offense to the rule of law principle still remain. The main scholar objections to the thesis sustain that the use of arbitration within Public Administration would violate the principle of 
unavailability of public interest. For this reason, this paper aims to analyze the principle of public interest from the perspective of its unavailability and supremacy, in accordance do Brazilian legal system, pointing some discussions around the effects on the use of arbitration by public entities. The methodology here used was the bibliographical review on the topic.

Keywords: Public Administration - Supremacy and Unavailability of Public Interest - State Arbitration

\section{REFERÊNCIAS BIBLIOGRÁFICAS}

BARROCAS, Manuel Pereira. Manual de Arbitragem. Coimbra: Almedina, 2010.

BARROSO, Luís Roberto. Curso de Direito Constitucional contemporâneo: os conceitos fundamentais e a construção do novo modelo. $4^{a}$ ed. São Paulo: Saraiva, 2013.

BRASIL. Lei 13.105, de 16 de março de 2015. Código de Processo Civil. Lei 9.307 de 23 de setembro de 1996. Lei da Arbitragem.

Lei 13.129 de 26 de maio de 2015. Lei que alterou, dentre outras, a Lei da Arbitragem.

CAHALI, Francisco José. Curso de Arbitragem: mediação: conciliação: resolução CNJ 125/2010. $5^{\mathrm{a}}$ ed. Revista e atualizada, de acordo com a Lei 13.129/2015 (Reforma da Lei de Arbitragem), com a Lei 13.140 (Marco Legal da Mediação) e o Novo CPC. São Paulo: Editora Revista dos Tribunais, 2015.

CÂMARA, Jacinto Arruda. SUNDFELD, Carlos Ari. O cabimento da Arbitragem nos Contratos Administrativos.

Revista de Direito Administrativo. Ed. Atlas. Disponível em
<http://bibliotecadigitalfgv.br/ojs/index.php/rda/article/viewFile/41529/40879>. Acesso em 02/02/2016.

DI PIETRO, Maria Sylvia Zanella. Direito Administrativo. 23a ed. São Paulo: Atlas. 2010.

As possibilidades de arbitragem em contratos administrativos. Disponível em <http://www.conjur.com.br/2015-set-24/interesse-publico-possibilidades-arbitragem-contratosadministrativos $2>$. Acesso em 02/02/2016.

DINAMARCO, Cândido Rangel. A arbitragem na teoria geral do processo. São Paulo: Malheiros. 2013.

FIGUEIRA JUNIOR, Joel Dias. Arbitragem (legislação nacional e estrangeira) e o monopólio jurisdicional. São Paulo: LTr, 1999.

FRANZONI, Diego. Arbitragem societária. Coleção Liebman/coordenação Teresa Arruda Alvim Wambier, Eduardo Talamini. São Paulo: Editora Revista dos Tribunais, 2015.

GRAU, Eros Roberto. Arbitragem e contrato administrativo. Revista da Escola Paulista da Magistratura. Volume 3. Número 2 - julho/dezembro 2002. São Paulo, SP: Escola Paulista da Magistratura. Imprensa Oficial do Estado.

Da arbitrabilidade de Litígios Envolvendo Sociedades de Economia Mista e da Interpretação de Cláusula Compromissória, In Revista de Direito Bancário, do Mercado de Capitais e da Arbitragem, ano 5. n. 18. outdez/2002. São Paulo: Editora Revista dos Tribunais.

JUSTEN FILHO, Marçal. Curso de Direito Administrativo. 2a ed. São Paulo: Saraiva, 2006. 
LEMES, Selma Ferreira. A arbitragem na Administração Pública - Fundamentos Juridicos e Eficiência Econômica. São Paulo: Quartier Latin. 2007

MEDAUAR, Odete. Direito Administrativo Moderno. 18ª ed. São Paulo: Editora Revista dos Tribunais, 2014.

MELLO, Celso Antonio Bandeira de. Curso de direito administrativo. 20a edição. São Paulo: Malheiros. 2006.

RENDERS, David; DEVOLVÉ, Pierre; TANQUEREL, Thierry; BOMBOIS, Thomas (Coautor). L'arbitrage en droit public. Bruxelles, Belgique: Bruylant, 2010. XVII (Centre d'études constitutionnelles et administratives; 31).

RODRIGUES, Marco Antonio. A fazenda pública no processo civil. São Paulo: Atlas, 2016.

SUPERIOR TRIBUNAL DE JUSTIÇA. Ag Rg no MS 11.308/DF. 1a Seção. Rel. Min. Luiz Fux. Jgto em 28.06.2006, DJ 14.08.2006. Disponível em <http://www.stj.jus.br/SCON/jurisprudencia/doc.jsp?livre=agravo+regimental+mandado+de+seguran\%E7a+1 $1308 \& b=A C O R \& p=t r u e \& t=J U R I D I C O \& l=10 \& i=9>$. Acesso em 12/02/2016.

TALAMINI, Eduardo. A (in)disponibilidade do interesse público: consequências processuais (composições em juízo, prerrogativas processuais, arbitragem e ação monitória). Disponível em $<$ https://www.academia.edu/231461/A_in_disponibilidade_do_interesse_p\%C3\%BAblico_consequ\%C3\%A Ancias_processuais $>$. Acesso em 29/03/2016.

SALLES, Carlos Alberto de. Arbitragem em contratos administrativos. Rio de Janeiro: Forense; São Paulo: Método, 2011.

VERÇOSA, Haroldo Malheiros Duclerc. Doze anos da lei de arbitragem: alguns aspectos ainda relevantes. In: Aspectos da Arbitragem Institucional. 12 anos da Lei 9.307/96. Org. Haroldo Malheiros Duclerc Verçosa. São Paulo: Malheiros. 2008.

WALD, Arnoldo. A recente evolução da arbitragem no direito brasileiro (1996-2001), In Reflexões sobre arbitragem: "In Memoriam" do Desembargador Cláudio Vianna de Lima. São Paulo: Editora LTR, 2002.

Novos Rumos para a Arbitragem no Brasil, In Revista de Direito Bancário e do Mercado de Capitais. vol.14/2001.p. 341-356. Out-Dez/2001. DTR \2001\411.

WALD, Arnoldo. SERRÃO, André. Aspectos Constitucionais e Administrativos da Arbitragem nas Concessões. Revista de Arbitragem e Mediação. vol. 16/2008. p.11-32. jan-mar/2008. São Paulo: Editora Revista dos Tribunais

Trabalho enviado em 21 de junho de 2016.

Aceito em 06 de outubro de 2016. 